\title{
BLACK ROSY FINCH SIGHTING ON BIG MUDDY CBC
}

CAROL F. BJORKLUND, 3634 McCallum Avenue, Regina, Saskatchewan. S4S 0S5

The 1990 Big Muddy Christmas Bird Count, centred on NE8-2-22 W2, about $12.4 \mathrm{~km}$ east of Big Beaver, Saskatchewan, took place on 2 January 1991. The day was clear, with temperatures ranging from $-23^{\circ} \mathrm{C}$ to $-27^{\circ} \mathrm{C}$, WSW wind at 8 to $16 \mathrm{kmph}$, and snow adrift to $8 \mathrm{~cm}$. Two parties, totalling six people, conducted the count.

As the party consisting of Carol Bjorklund and Martin Bailey drove along a road in the higher elevations southwest of Big Muddy Lake, a single bird flew along the roadside just ahead of the truck. It flew low to the ground, moving from weed to weed at the edge of the road. The upper parts of the bird were uniformly dark. When the truck stopped, the bird flew across the road and landed on the ground directly beneath the driver's side window, remaining there, looking up at the window. It seemed undisturbed by the presence of the vehicle and went about its business in clear view of the observers. After a few long minutes, it flew around the back of the truck, and again landed on the ground, this time under the off-side window, where it once more paused, feeding and looking up at the observers. Over five minutes later, the bird flew across in front of the truck, over a hill and was not seen again.

The bird had a yellow bill, black forehead and grey crown. The face was black, as were the eyes. Its breast was black and the belly deep red. Its back was blackish; rump colour was not noted because of angle view. The wings were blackish-brown with rosy patches. It was obvious at once that the bird was a Rosy Finch, but it was a surprise to compare field notes with field guides and other sources to come up with none other than the "Black" Rosy Finch. ${ }^{1,2,4,5}$ A search of available literature revealed no records of the "Black" Rosy Finch for Saskatchewan or Canada. The "Black" Rosy Finch was formerly considered a full species but is now designated a subspecies of the Rosy Finch.

According to the third edition of Peterson's Western Birds, the range of the "Black" Rosy Finch is southwestem Montana, central Idaho, western Wyoming, northeastem Nevada and northem Utah. Peterson cites the bird's habitat as "rocky summits, alpine cirques, and snowfields ... winters in open country at lower levels, spreading onto plains., ${ }^{, 3}$

Three camera bodies and a variety of lenses were present in the truck at the time of this sighting, but none was used! In this case the joy of birding was in beholding and not in documenting.

1. FARRAND, J., ed. 1983. The Audubon Society master guide to birding. Alfred A. Knopf, New York.

2. GODFREY, W. E. 1986 The birds of Canada. Natl. Mus. Nat. Sci., Ottawa.

3. PETERSON, R. T. 1990. A field guide to western birds. Houghton, Mifflin, Co., Boston.

4. ROBBINS, C.S., B. BRUUN and S. ZIM. 1983. A guide to field identification: birds of North America. Golden Press, New York.

5. SCOTT, S.L., ed. 1987. Field guide to the birds of North America. National Geographic Society, Washington D.C. 


\section{CHRISTMAS BIRD AND MAMMAL COUNTS ANNOUNCEMENT}

Count period this year is from Saturday, 14 December 1991 to Thursday, 2 January 1992. Count area should be a circle $24 \mathrm{~km}(15 \mathrm{mi}$.) in diameter. Counts must be a minimum of three hours in duration. Count forms will be mailed to compilers who submitted counts in 1990. Anyone else wishing to send in a count please write for forms to:

Wayne C. Harris

Box 414

Raymore, Saskatchewan

SOA 3J0

Reports of counts should be sent to Wayne as soon as possible after they are taken. To be included in the report in the March 1992 Blue Jay, they must reach Wayne by 12 January 1992 .

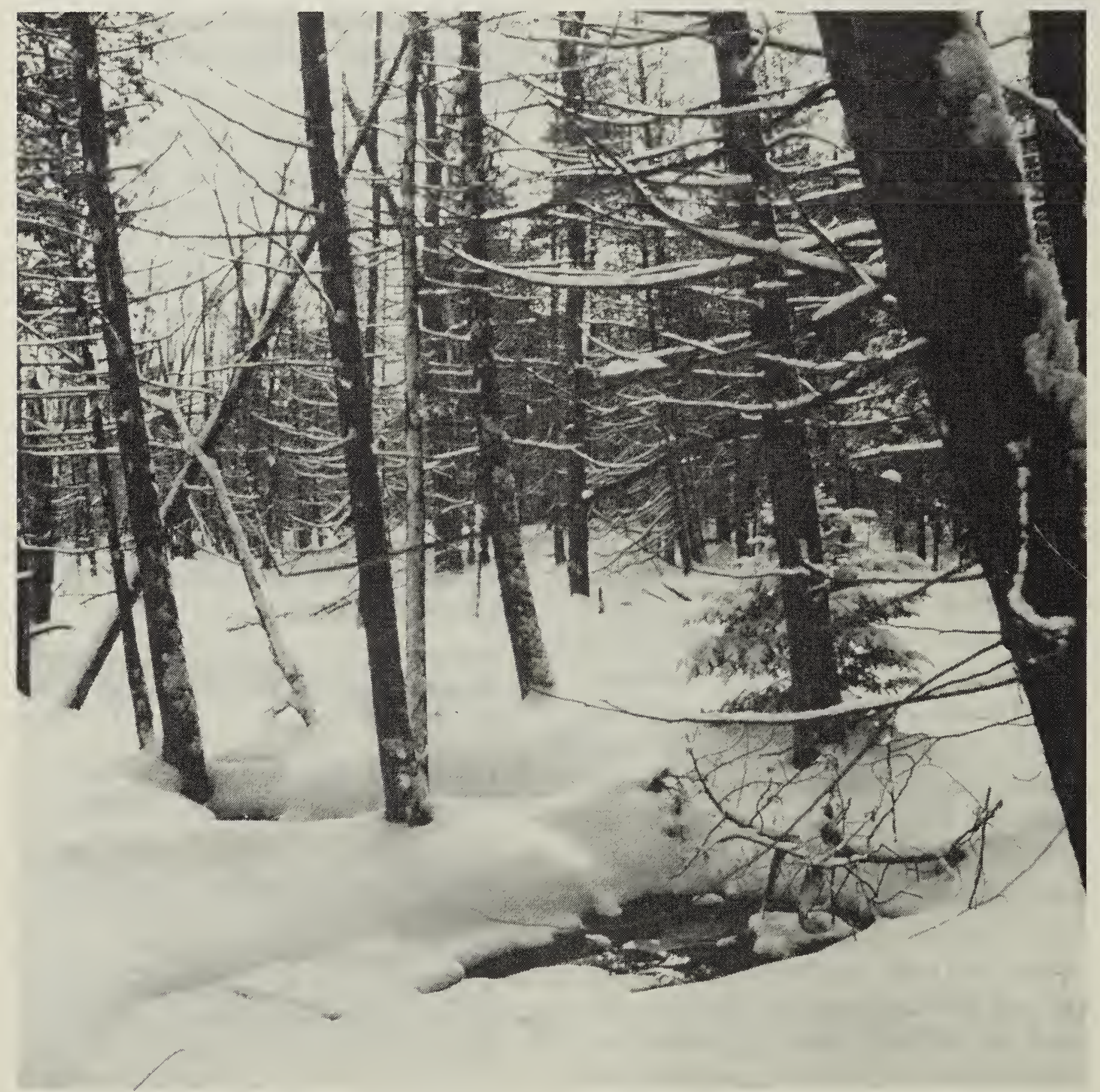

